\title{
The Effects of Anabasine and the Alkaloid Extract of Nicotiana glauca on Lepidopterous Larvae
}

\author{
Michelle Zammit ${ }^{1}$, Claire Shoemake ${ }^{1}$, Everaldo Attard ${ }^{2} \&$ Lilian M. Azzopardi $^{1}$ \\ ${ }^{1}$ Department of Pharmacy, Faculty of Medicine and Surgery, University of Malta, Msida, Malta \\ ${ }^{2}$ Division of Rural Sciences and Food Systems, Institute of Earth Systems, University of Malta, Msida, Malta \\ Correspondence: Michelle Zammit, Department of Pharmacy, Faculty of Medicine and Surgery, University of \\ Malta, Msida, Malta. E-mail: michelle.zammit.01@um.edu.mt
}

\author{
Received: March 25, 2014 Accepted: May 12, 2014 Online Published: May 27, 2014 \\ doi:10.5539/ijb.v6n3p46 \\ URL: http://dx.doi.org/10.5539/ijb.v6n3p46
}

\begin{abstract}
For several decades, Nicotiana glauca has been known for its content of the pyridine alkaloid, anabasine. The toxicological effects of this metabolite have been extensively studied, as opposed to its potential insecticidal activity. The anabasine content of leaves of $N$. glauca, collected from Malta, was $0.258 \pm 0.0042 \%$ as determined by High Performance Liquid Chromatography. In the Pieris rapae larval bioassay, the median effective concentrations of anabasine and the alkaloid extract were 0.572 and $1.202 \mathrm{mg}$ per larva, respectively. The presence of other interfering metabolites may have resulted in this elevated $\mathrm{EC}_{50}$ for the crude extract. Anabasine is quoted to be a very toxic alkaloid not solely to insects, but also to other animals, and its use in minute concentrations in insect traps may well prove it to be an effective natural insecticide.
\end{abstract}

Keywords: Nicotiana glauca, anabasine, Pieris rapae, insecticide

\section{Introduction}

Extracts of plants have been used as insecticides by humans since before the time of the ancient Romans, a practice that continues to present day with many of the species of plants known to have insecticidal properties (Balandrin, Klocke, Wurtele, \& Bollinger, 1985; Isman, 2006). Plant products may be more rapidly degraded in the environment than synthetic compounds and some may have increased specificity that may favour insects beneficial to the plant. However, sublethal effects may still be experienced by these natural enemies or beneficial insects (Desneux, Decourtye, \& Delpeuche, 2007).

The Nicotiana genus is well known for its insecticidal effects (Puripattanavong, Songkram, Lomlim, \& Amnuaikit, 2013). Nicotiana glauca belongs to the plant family Solanaceae and is an evergreen, bluish green, erect, slender, sparsely-branched perennial, soft-woody shrub to small tree; usually up to $4 \mathrm{~m}$ tall or more which reproduces only by seeds (Halvorson \& Guertin, 2003). N. glauca, Tree Tobacco or Indian Tobacco, was native to South America but is now naturalized in California, Australia, the Mediterranean, and Africa (Ollerton et al., 2012).

In Malta, the Tobacco Tree was introduced as an ornamental, but is now extensively naturalised especially on rubble (Weber \& Kendzior, 2006). As its Maltese name implies (Tabakk tas-swar) it is also commonly seen growing on Maltese bastion walls. The stems are slender and loosely branching and break easily. The leaves are evergreen and alternate, and covered with a thin waxy coating on both surfaces and with a whitish powder which rubs off easily. When crushed the leaf gives off an odour that is always described as "unpleasant". The tubular flowers are yellow, about $5 \mathrm{~cm}$ long, and are borne on large leafless branches at the ends of the stems throughout the year. The five lobes are very short, so there is little spread. The seedpods are brown, contain many seeds, 1-1.25 cm long, egg-shaped or oblong, on curving stalks from which they hang downward. The seeds are dark brown and kidney-shaped, about $0.3 \mathrm{~cm}$ long, with a rough surface (Haslam, Sell, \& Wosley, 1977; Halvorson \& Guertin, 2003).

Like other Nicotiana species, $N$. glauca is known for the presence of pyridine alkaloids (Andersson, Wennström $\&$ Gry, 2003). The alkaloids nicotine and anabasine (Figure 1) have been widely used as pesticides. Nicotine is the predominant alkaloid in Nicotiana tabacum (da Silva et al., 2013) and Nicotiana rustica (Lisko, Stanfill, Duncan \& Watson, 2013) whereas anabasine is the predominant alkaloid in Nicotiana glauca (Lisko et al., 2013; 
Slyn'ko, Tatarova, Shakirov, \& Shul'ts, 2013). Nicotine is a powerful insecticide towards aphids (Puripattanavong et al, 2013) and larvae of lepidopterous pests (Shao, Dong, \& Zhang, 2007). Both nicotine and anabasine are well known to exert their insecticidal effect by interacting with nicotinic acetylcholine receptors (Shao et al., 2007; Glennon \& Dukat, 2000).<smiles>CN1CCCC1c1cccnc1</smiles>

Nicotine<smiles>c1cncc(C2CCCN2)c1</smiles>

Nornicotine<smiles>c1cncc(C2CCCCN2)c1</smiles>

Anabasine

Figure 1. Anabasine (first named Neonicotine) and other pyridine alkaloids of Nicotiana species, Nicotine and Nornicotine

Anabasine is the major alkaloid in N. glauca (Hawley, 1977; Saitoh, Noma, \& Kawashima, 1985; Abd-El-Khalek, Abd-El-Nabey, \& Abdel-Gaber, 2012) and all alkaloidal effects of the plant are attributed to this compound (Keeler, Balls, \& Panter, 1981; Lisko et al., 2013). In N. glauca, anabasine makes up 1.2\% of the plant material in fruits and $1.1 \%$ of the plant material in leaves. The roots, flowers and stems contain lower quantities of anabasine (Khafagy \& Metwally, 1968). Anabasine [3-(2-Piperidinyl)pyridine, 2-(3-pyridyl)piperidine], neonicotine, $\mathrm{C}_{10} \mathrm{H}_{14} \mathrm{~N}_{2}$, molecular weight $=162.23$ (Harborne \& Baxter, 1995) was first synthesised in 1930 by Smith. It contains a pyridine ring attached at a $\beta$-position to the $\alpha$-position of a pyrrolidine or piperidine ring, chemically very closely related to nicotine and the compound was therefore first named neonicotine (Ginsburg \& Schmitt, 1935). Anabasine is a colourless viscous liquid which turns brown upon aging in contact with air. It has a boiling point of $280{ }^{\circ} \mathrm{C}$ to $281{ }^{\circ} \mathrm{C}$ and is less volatile with steam than is nicotine. Anabasine freezes at $9{ }^{\circ} \mathrm{C}$. The compound is very stable, appreciably basic in reaction, forms salts in typical alkaloidal fashion and is soluble in water in all proportions and in most organic solvents (Haag, 1933).

This study is aimed at isolating and detecting anabasine in local Nicotiana glauca collected in Malta and testing of anabasine for pesticidal properties on cabbage white caterpillars (Pieris rapae) so as to determine the concentration of anabasine in the local plant and its effectiveness against local larvae, Data regarding anabasine content in the Maltese plant was not available in literature.

\section{Method}

\subsection{Chemical Investigations}

\subsubsection{The Extraction and Separation Procedure}

The leaves of approximately the same size of $N$. glauca were collected from Iklin in Malta, in July whilst the plants were flowering. The leaves were identified. The extraction and separation procedures for anabasine followed were those modified from standard procedures for alkaloidal extraction (Trease \& Evans, 1978) and separation (Cunniff, 1995). Briefly, the leaves were dried at $35{ }^{\circ} \mathrm{C}$ for 48 hours and $10 \mathrm{~g}$ of the resulting powder was then shaken for 4 hours at $200 \mathrm{rpm}$ with $200 \mathrm{ml}$ of $0.5 \%$ sodium hydroxide. The volume of the filtrate was reduced to $70 \mathrm{ml}$ at $35{ }^{\circ} \mathrm{C}$. $20 \mathrm{ml}$ of chloroform were added and after five additions, the combined chloroform solution was then added to five portions of $20 \mathrm{ml}$ of $0.05 \mathrm{M}$ hydrochloric acid. The combined acidified aqueous extract was neutralised with ammonia solution to a $\mathrm{pH}$ of 7 .

\subsubsection{Chemical Test Analysis}

The solutions prepared after the extraction and separation procedure were tested with the Dragendorff reagent (Potassium bismuth iodide) (Wagner \& Bladt, 1996). UV analysis, using a Pharmacia LKB Ultrospec III UV/Vis Spectrophotometer was carried out on both the acidified and the neutralised extracts after the determination of the wavelengths at which to test. Anabasine standard (Sigma-Aldrich Chemie GmbH Germany) was used for all the analyses as control.

The extract was analysed by a Shimadzu LC-10A HPLC (Shimadzu, Kyoto, Japan) using a C18 MicroBondapak column, $250 \times 4.6 \mathrm{~mm}, 10 \mathrm{~mm}$, with a mobile phase of $40 \%$ methanol containing $0.2 \%$ phosphoric acid buffered to $\mathrm{pH} 7.25$ with triethylamine, a flow rate of $0.5 \mathrm{ml} / \mathrm{min}$ and a run time of 20 minutes (Saunders \& Blume, 1981). 
The anabasine standard was injected at the same concentration using different volumes to obtain different values for the calibration of absorbance with anabasine concentration. The same procedure was repeated in duplicate for the $N$. glauca extract. Loss of anabasine and total anabasine content was calculated.

\subsection{Pharmacological Investigations}

\subsubsection{Rearing of Pieris rapae}

P. rapae larvae were obtained from fields and grown in cages until they formed pupae. After a few days the pupae developed into butterflies and these were grown in special cages and mated. The females were then left to lay eggs which hatched into new larvae which were then used in the experiment (Dickson, 1992).

\subsubsection{Topical Bioassay With Anabasine Standard and N. glauca Extract}

The 48-hr topical bioassay method used to test the Pieris rapae larvae with anabasine was one modified from an established method (Hsin \& Coats, 1987; Wright et al., 2000). Larvae were examined after 48 hours; the criteria used to judge paralysis was placing the larvae on a cabbage leaf on the bench surface for 10 mins with constant, light prodding.

In the reference method, $1 \mu \mathrm{L}$ of insecticide was applied to each organism. Due to practical reasons dilutions were adjusted to $200 \mu \mathrm{L}$.

Briefly, one larva was placed in each of thirty five wells of six-well plates (Nunc AS, Copenhagen, Denmark). Six anabasine dilutions were prepared containing the anabasine standard and $0.2 \mathrm{ml}$ of each dilution was pipetted in five of the wells containing the larvae, with final concentrations ranging between $0.025 \mathrm{mg}$ to $5 \mathrm{mg}$ per larva. $0.2 \mathrm{ml}$ of distilled water was pipetted in another five wells. The well plates were left in a well-lit, well-ventilated room at $25^{\circ} \mathrm{C}$ for $24 \mathrm{~h}$. The solution was then dried from the wells and the caterpillars left inside the wells in the same room for a further $24 \mathrm{~h}$. The larvae were then slowly lifted out of the wells one after the other and placed on a cabbage leaf on the bench surface for 10min and prodded. Their behaviour was noted.

The same procedure was followed for the Nicotiana glauca extracts. In this case, one larva was placed in each of ninety wells. Eight dilutions of $N$. glauca neutralised extract from 2.1 .1 were prepared and $0.2 \mathrm{ml}$ of each dilution was pipetted in ten of the wells containing the larvae with final concentrations ranging between $0.7 \mathrm{mg}$ to $2.8 \mathrm{mg}$ per larva. $0.2 \mathrm{ml}$ of distilled water was pipetted in another ten wells.

The range of concentrations $(0.7 \mathrm{mg}$ to $2.8 \mathrm{mg}$ ) for the $N$. glauca extract was selected such that the range of activity included dilutions at which the alkaloids were not active and dilutions which exhibited $100 \%$ activity. For both standard and extract, the median effective concentration $\left(\mathrm{EC}_{50}\right)$ was calculated using LdP LineR software Version 1.0 (Ehabsoft, 2014) based on Finney Probit Analysis (1971).

\subsubsection{Statistical Analysis}

One-Way Analysis of Covariance was used to determine if there is any statistical significant difference between the activity of anabasine standard and the anabasine extracted from $N$. glauca. This was carried out using the program BMDP statistical software (Engelman, 1990). Following transformation and normalization of the data, the two trends were compared using non-linear regression (Akaike's method) and the respective $\mathrm{EC}_{50}$ values were compared by using GraphPad Prism version 5.00 for Windows, GraphPad Software, San Diego California USA, www.graphpad.com. P values less than 0.05 , were considered as significant.

\section{Results}

In the chemical investigations, some of the Nicotiana glauca extracts, alongside the anabasine, tested positive with the Dragendorff's reagent, which was used as the alkaloid identification test. In particular, the acidified and the final neutralised solutions tested positive. The presence of anabasine in the extracts was further confirmed by the spectrophotometric analysis giving peaks at 231 and $257 \mathrm{~nm}$ (Table 1). HPLC analysis revealed that the average retention time of anabasine in the sample was $10.368 \pm 0.03 \mathrm{~min}$ and the average concentration of anabasine in the sample was $258.633 \pm 4.217 \mathrm{ppm}$ after adding the calculated $0.73 \%$ loss (Figure 2). The similarity index of the anabasine in the sample to the standard was $0.999(\mathrm{v}=4)$. A $0.73 \%$ loss was the value obtained in all cases of the different standard concentrations showing a high degree of precision.

The bioassay on Pieris rapae larvae showed that the standard anabasine exhibited an $\mathrm{EC}_{50}$ of $0.572 \mathrm{mg} / \mathrm{larva}$ (or $0.286 \%$ ) while the $N$. glauca final extract exhibited an activity of $1.202 \mathrm{mg} / \mathrm{larva}$ (or $0.601 \%$ ). 
Table 1. UV absorbance at two wavelengths for crude $N$. glauca extracts and pure anabasine

\begin{tabular}{ccc}
\hline \multirow{2}{*}{ Solution } & \multicolumn{2}{c}{ Absorbance } \\
\cline { 2 - 3 } & $231 \mathrm{~nm}$ & $257 \mathrm{~nm}$ \\
\hline Anabasine standard & 3.793 & 3.661 \\
Acidified extract & 0.769 & 2.295 \\
Neutralised extract & 2.417 & 2.153 \\
\hline
\end{tabular}

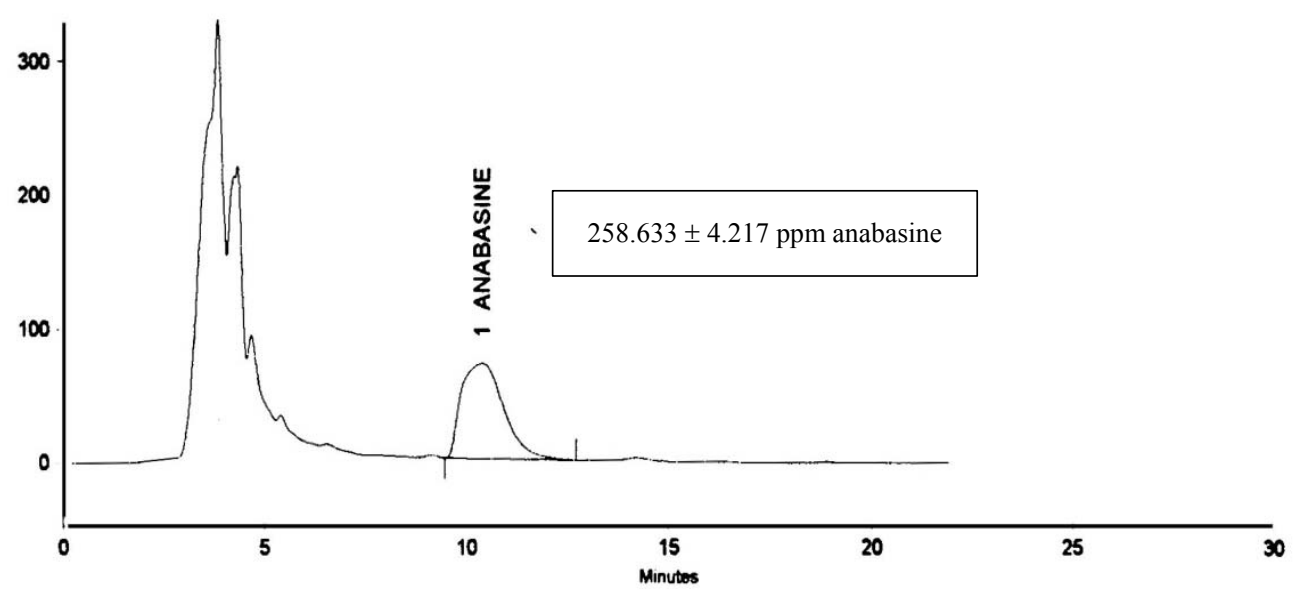

Figure 2. HPLC spectrum of $N$. glauca extract. The average retention time of anabasine in the sample was $10.368 \pm 0.03 \mathrm{~min}$ and the average concentration of anabasine in the sample was $258.633 \pm 4.217 \mathrm{ppm}$ after adding the calculated $0.73 \%$ loss

Table 2. $\mathrm{EC}_{50}$ of standard and extract. This difference in value is not statistically significant

\begin{tabular}{lllllll}
\hline & $\mathrm{EC}_{50}{ }^{\mathrm{a}}(\mathrm{mg} /$ larva $)$ & lower limit $^{\mathrm{b}}$ & upper limit $^{\mathrm{b}}$ & $\mathrm{EC}_{50}(\%)$ & ANCOVA $^{\mathrm{c}}$ & EC $_{50}$ Comparison $^{\mathbf{d}}$ \\
\hline Standard & 0.572 & 0.466 & 0.702 & 0.286 & $\mathrm{p}=0.1554$ & $\mathrm{p}<0.001$ \\
Extract & 1.202 & 1.091 & 1.324 & 0.601 & & \\
\hline
\end{tabular}

${ }^{\mathrm{a}} \mathrm{LDPline;}{ }^{\mathrm{b}} 95 \%$ Confidence Intervals; ${ }^{\mathrm{c}}$ ANCOVA for slopes; ${ }^{\mathrm{d}}$ Non-linear regression analysis.

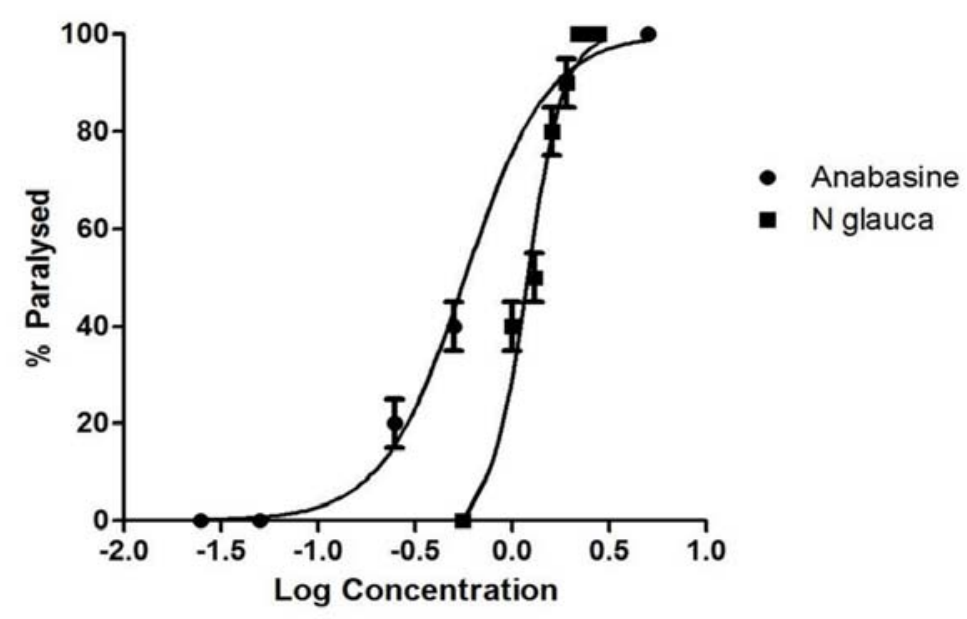

Figure 3. Percentage paralysed larvae with the anabasine and N. glauca extract. The bioassay on Pieris rapae larvae showed that the standard anabasine exhibited an $\mathrm{EC}_{50}$ of $0.572 \mathrm{mg} / \mathrm{larva}$ (or $0.286 \%$ ) while the $N$. glauca final extract exhibited an activity of $1.202 \mathrm{mg} /$ larva (or $0.601 \%$ ) 


\section{Discussion}

\subsection{Chemical Investigations}

Dragendorff's reagent (Potassium bismuth iodide) combines with alkaloids to give a characteristic orange brown precipitate. The alkaline and organic solutions did not result in a precipitate as opposed to the acidified and the final neutralised solution. In the latter two cases, the alkaloids must have been extracted from the plant by the sodium hydroxide, into chloroform and then into the hydrochloric acid showing that all the alkaloids had been extracted during this process. Anabasine standard gives two prominent peaks at $231 \mathrm{~nm}$ and $257 \mathrm{~nm}$ when analysed spectrophotometrically. Both the $N$. glauca acidified and neutralised extracts gave absorbances at both these wavelengths, thus confirming the presence of anabasine and/or related pyridine alkaloids (Shkurina,et al, 1960). The content of nicotinic alkaloids in various plants has been investigated using various methods. The wild form of N. glauca found in Egypt was found to contain 1.2\% and $1.1 \%$ anabasine in the fruits and leaves, respectively (Khafagy \& Metwally, 1968). More recently, anabasine content was determined by gas chromatography. This constituent made up $0.2 \%$ of the Israeli $N$. glauca (Mizrachi, Levy, \& Goren, 2000). In another study, it was found that the young plant in Arizona contained $0.233 \pm 0.0061 \%$ anabasine (Keeler et al., $1981)$ which concords very closely with the results obtained in this study $(0.258 \pm 0.0042 \%)$. In another HPLC determination, the anabasine content of $N$. glauca plants in California, was $0.143 \%$ (Plumlee, Holstege, Blanchard, Fiser, \& Galey, 1993).

The alkaloidal content in plants changes with factors such as environmental conditions, season and age of the plant. In fact, the results obtained in the this study $(0.258 \pm 0.0042 \%)$ reflect the alkaloidal content of the plant at the time of collection of the leaves (Cordell, 1994) and compares well with the content reported in studies performed on plants collected in other counries.

\subsection{Pharmacological Investigations}

Control larvae and larvae that were not affected by the applied solutions described in 2.2.2, moved off from the cabbage leaf they were placed upon, and when placed again on the leaf, they continued feeding. However, those that were affected by the treatments, were unable to move the appendages. These larvae were considered as paralysed. These can be distinguished from dead larvae as in such cases the larvae would be limp, discoloured and brown in colour. Only paralysis was observed with the alkaloidal concentrations used in this study.

The water content in controls $(200 \mu \mathrm{L})$ did not have any physical effects on the larvae, such as the respiratory system (Fraenkel \& Herford, 1938).

The bioassay with the standard anabasine determined the effect of anabasine on Pieris rapae larvae $(0.572$ $\mathrm{mg} / \mathrm{larva}$ or $0.286 \%)$. The higher $\mathrm{EC}_{50}$ in the extract $(1.202 \mathrm{mg} / \mathrm{larva}$ or $0.601 \%)$ demonstrates that alongside anabasine and other possible nicotinic alkaloids, interfering substances that reduced the response of the caterpillars to anabasine may be present. This occurred in spite of the fractionation and partial purification of the alkaloids in the extract. The rate of activity, as determined through the Analysis of Covariance, did not show any significant difference between the two treatments $(p=0.1554)$. To a certain extent this explains a similar activity between the two treatments and hence it can be partially concluded that pyridine alkaloids are provoking the effect for the $N$. glauca extract as is evident in the anabasine treatment. On the other hand, from the $\mathrm{EC}_{50}$ comparative analysis, anabasine showed a higher potency compared to the $N$. glauca extract. This was observed in other studies that clearly show that the single constituents are in general more potent than the crude extract (Keeler, Crowe, \& Lambert, 1984; Ganfon et al., 2012; Rizvi et al., 2010). Although it is expected that the extract with a known concentration of anabasine could be compared to the pure anabasine standard, the presence of interfering substances will definitely reduce the potency of the $N$. glauca extract. It is known that alkaloids interact with triterpenoids and derivatives (Mali \& Borges, 2003), amino acid decarboxylase enzymes (Beeker, Smith \& Pennington, 1992) amongst other metabolites. Besides the pyridine alkaloids, N. glauca stores such metabolites (Bagni, Creus, \& Pistocchi, 1986; Skliar, Curino, Milanesi, Benassati, \& Boland, 2000). Some studies argue that crude extracts may have a better activity than pure single metabolites (Keung, Lazo, Kunze, \& Vallee, 1996). This most probably would be possible if the crude extract contains solely or in a relatively high concentration the class of compounds represented by the pure single metabolites. In spite of all this, the alkaloidal effects of the $N$. glauca extract may be attributed to anabasine, as already noted in other phytochemical studies and bioassays (Keeler et al., 1981).

\section{Conclusion}

Attention has recently been directed to use of botanical insecticides vs. the use of synthetic insecticides especially in developing countries where synthetic insecticides are not affordable (Isman, 2006), where there is 
resistance to conventional synthetic insecticides as well as increased concern for the environment. Research into botanicals containing active insecticidal phytochemicals is becoming increasingly important to help address these issues.

It has already been reported in literature that N. glauca is toxic to humans and other mammals (Haag, 1933; Keeler et al., 1981; Panter, Keeler, James, \& Bunch, 1992; Castorena, Garriott, Barnhardt, \& Shaw, 1987; Plumlee et al., 1993; Mellick, Makowski, Mellick, \& Borger, 1999). Nicotiana alkaloids have been also detected in animal products such as milk (Panter \& James, 1990).

Although the potential toxicity of this extract may not justify the use of $N$. glauca extracts as a direct insecticide, with suitable chemoreception metabolites (van Loon, 1990), this extract can be confined in pheromone traps, hence reducing the incidence of mammalian or beneficial insect toxicity. In conclusion, this study has determined the presence and quantity of the alkaloid anabasine in local $N$. glauca extract which is comparable to that reported in earlier documented studies in other countries and its potential effectiveness against the larvae of local Pieris rapae.

\section{References}

Abd-El-Khalek, D. E., Abd-El-Nabey, B. A., \& Abdel-Gaber, A. M. (2012). Evaluation of Nicotiana Leaves Extract as Corrosion Inhibitor for Steel in Acidic and Neutral Chloride Solutions. Portugaliae Electrochimica. Acta., 30(4), 247-259. http://dx.doi.org/10.4152/pea.201204247

Andersson, C., Wennström, P., \& Gryo, J. (2003). Nicotine alkaloids in solanaceous food plants. TemaNord, Copenhagen, Denmark.

Bagni, N., Creus, J., \& Pistocchi, R. (1986). Distribution of Cadaverine and Lysine Decarboxylase Activity in Nicotiana glauca Plants. Journal of Plant Physiology, 125(1), 9-15. http://dx.doi.org/10.1016/S0176-1617(86)80238-3

Ballandrin, M. F., Klocke, J. A., Wurtele, E. S., \& Bollinger, W. H. (1985). Natural plant chemicals: Sources of industrial and medicinal materials. Science, 228, 1154-60. http://dx.doi.org/10.1126/science.3890182

Beeker, K., Smith, C., \& Pennington, S. (1992). Effect of cocaine, ethanol or nicotine on ornithine decarboxylase activity in early chick embryo brain. Developmental Brain Research, 69(1), 51-57. http://dx.doi.org/10.1016/0165-3806(92)90121-C

Castorena, J. L., Garriott, J. C., Barnhardt, F. E., \& Shaw, R. F. (1987). A fatal poisoning from Nicotiana glauca. Clinical Toxicology, 25(5), 429-435. http://dx.doi.org/10.1016/0378-8741(88)90058-X

Cordell, G. A. (Ed.). (1994). The Alkaloids. Chemistry and Pharmacology (Vol. 44). Access Online via Elsevier.

Cunniff, P. (Ed.). (1995). Official methods of analysis of AOAC International (16th ed.,Vol. 1). Virginia: AOAC international.

da Silva, F. R., Erdtmann, B., Dalpiaz, T., Nunes, E., Ferraz, A., Martins, T. L., ... da Silva, J. (2013). Genotoxicity of Nicotianatabacum leaves on Helix aspersa. Genetics and Molecular Biology, 36(2), 269-275. http://dx.doi.org/10.1590/S1415-4757201300500002

Desneux, N., Decourtye, A., \& Delpeuch, J. M. (2007). The Sublethal effects of Pesticides on Beneficial Arthropods. Annual Revie of Entomology, http://dx.doi.org/10.1146/annurev.ento.52.110405.091440

Dickson, R. (1992). A lepidoperist's handbook (2nd ed., pp. 32-57). Middlesex: The Amateur Entomologist's Society. (The Amateur Entomologist, Vol. 13).

Ehabsoft. (2014). http://www.ehabsoft.com/ldpline

Engelman, L. (1990). One-way analysis of covariance. In W. J. Dixon, M. B. Brown, L. Engelman, \& R. I. Jennrich (Eds.), BMDP Statistical Software Manual (Vol. 2). Berkley: University of California Press.

Finney, D. J. (1971). Probit analysis (3rd ed.). New York, Ny: Cambridge University Press.

Fraenkel, G., \& Herford, G. V. B. (1938). The respiration of insects through the skin. Journal of Experimental Biology, 15(2), 266-280.

Ganfon, H., Bero, J., Tchinda, A. T., Gbaguidi, F., Gbenou, J., Moudachirou, M., ... Quetin-Leclercq, J. (2012). Antiparasitic activities of two sesquiterpenic lactones isolated from Acanthospermumhispidum DC. Journal of Ethnopharmacology, 141(1), 411-417. http://dx.doi.org/10.1016/j.jep.2012.03.002 
Ginsburg, J. M., \& Schmitt, J. B. (1935). Comparative toxicity of anabasine and nicotine sulphate to insects. Journal of Agricultural Research, 51, 349-354.

Glennon, R. A., \& Dukat, M. (2000). Central nicotinic receptor ligands and pharmacophores. Pharmacochemistry Library, 31, 103-114. http://dx.doi.org/10.1016/S0165-7208(00)80006-9

Haag, H. B. (1933). A contribution to the pharmacology of anabasine. The Journal of Pharmacology and Exeperimental Therapeutics, 48, 95-104.

Halvorson, W. L., \& Guertin, P. (2003). Factsheet for Nicotiana glauca Graham. Retrieved from http://sdrsnet.srnr.arizona.edu/data/sdrs/ww/docs/nicoglau.pdf

Harborne, J. B., \& Baxter, H. (Eds.). (1995). Phytochemical dictionary: A handbook of bioactive compounds from plants. United Kingdom: Taylor \& Francis. http://dx.doi.org/10.1016/0031-9422(95)90167-1

Haslam, S. M., Sell, P. D., \& Wolseley, P. A. (1977) A Flora of the Maltese Islands. Malta University Press, Malta.

Hawley, G. G. (1977). The condensed chemical dictionary. Van Nostrand Reinhold, London.

Hsin, C. Y., \& Coats, J. R. (1987). Bendiocarb metabolism in adults and larvae of the southern corn rootworm, Diabrotica undecimpunctata howardi. Journal of Pesticide Science, 12, 405-413. http://dx.doi.org/10.1584/jpestics.12.405

Isman, M. B. (2006). Botanical Insecticides, Deterrents, and Repellents in Modern Agriculture and an Increasingly Regulated World. Annual Review of Entomology, 51, 45-66. http://dx.doi.org/10.1146/annurev.ento.51.110104.151146.

Keeler, R. F., Balls, L. D., \& Panter, K. (1981). Teratogenic effects of Nicotiana glauca and concentration of anabasine, the suspect teratogen in plant parts. The Cornell Veterinarian, 71, 47-53.

Keeler, R. F., Crowe, M. W., \& Lambert, E. A. (1984). Teratogenicity in swine of the tobacco alkaloid anabasine isolated from Nicotiana glauca. Teratology, 30(1), 61-69. http://dx.doi.org/10.1002/tera.1420300109

Keung, W. M., Lazo, O., Kunze, L., \& Vallee, B. L. (1996). Potentiation of the bioavailability of daidzin by an extract of Radix puerariae. Proceedings of the National Academy of Sciences, 93(9), 4284-4288. http://dx.doi.org/10.1073/pnas.93.9.4284

Khafagy, S. M., \& Metwally, A. M. (1968). Phytochemical study of Nicotiana glauca R. Grah. grown in Egypt. Journal of Pharmaceutical Sciences, U.A.R., 9, 83-97.

Lisko, J. G., Stanfill, S. B., Duncan, B. W., \& Watson, C. H. (2013). Application of GC-MS/MS for the Analysis of Tobacco Alkaloids in Cigarette Filler and Various Tobacco Species. Analytical Chemistry, 85(6), 3380-3384. http://dx.doi.org/10.1021/ac400077e

Mali, S., \& Borges, R. M. (2003). Phenolics, fibre, alkaloids, saponins, and cyanogenic glycosides in a seasonal cloud forest in India. Biochemical Systematics and Ecology, 31(11), 1221-1246. http://dx.doi.org/10.1016/S0305-1978(03)00079-6

Mellick, L. B., Makowski, T., Mellick, G. A., \& Borger, R. (1999). Neuromuscular Blockade After Ingestion of Tree Tobacco (Nicotiana glauca). Annals of Emergency Medicine, 34(1), 101-104. http://dx.doi.org/10.1016/S0196-0644(99)70280-5

Mizrachi, N., Levy, S., \& Goren, Z. (2000). Fatal poisoning from Nicotiana glauca leaves: identification of anabasine by gas-chromatography/mass spectrometry. Journal of Forensic Sciences, 45(3), 736-741.

Ollerton, J., Watts, S., Connerty, S., Lock, J., Parker, L., Wilson, I., ... Stout, J. C. (2012). Pollination ecology of the invasive tree tobacco Nicotiana glauca: Comparisons across native and non-native ranges. Journal of Pollination Ecology, 9(12), 85-95.

Panter, K. E., \& James, L. F. (1990). Natural plant toxicants in milk: a review. Journal of Animal Science, 68(3), 892-904.

Panter, K. E., Keeler, R. F., James, L. F., \& Bunch, T. D. (1992). Impact of plant toxins on fetal and neonatal development: A review. Journal of Range Management, 52-57. http://dx.doi.org/10.2307/4002525

Plumlee, K. H., Holstege, D. M., Blanchard, P. C., Fiser, K. M., \& Galey, F. D. (1993). Nicotiana glauca toxicosis of cattle. Journal of Veterinary Diagnostic Investigation, 5(3), 498-499. http://dx.doi.org/10.1177/104063879300500340 
Puripattanavong, J., Songkram, C., Lomlim, L., \& Amnuaikit, T. (2013). Development of Concentrated Emulsion containing Nicotiana tabacum Extract for Use as Pesticide. Journal of Applied Pharmaceutical Science, 3(11), 016-021.

Rizvi, W., Rizvi, M., Kumar, R., Kumar, A., Shukla, I., \& Parveen, M. (2010). Antibacterial Activity of Ficuslyrata - An In vitro Study. The Internet Journal of Pharmacology, 8(2), 7.

Saitoh, F., Noma, M., \& Kawashima, N. (1985). The alkaloid content of sixty Nicotiana species. Phytochemistry, 24(3), 477-480. http://dx.doi.org/10.1016/S0031-9422(00)80751-7

Saunders, J. A., \& Blume, D. E. (1981). Quantitation of major tobacco alkaloids by high performance liquid $\begin{array}{lllll}\text { chromatography. } & \text { Journal }\end{array}$ http://dx.doi.org/10.1016/S0021-9673(00)81822-1.

Shao, Y. M., Dong, K., \& Zhang, C. X. (2007). The nicotinic acetylcholine receptor gene family of the silkworm, Bombyxmori. BMC genomics, 8(1), 324. http://dx.doi.org/10.1186/1471-2164-8-324

Shkurina, T. N., Alashev, F. D., Zvorykina, V. K., \& Gol'dfarb, Y. L. (1960). Ultraviolet absorption spectra of some pyridine and nicotine derivatives. Bulletin of the Academy of Sciences of the USSR, Division of chemical science, 9(6), 1041-1045. http://dx.doi.org/10.1007/BF00903985

Skliar, M., Curino, A., Milanesi, L., Benassati, S., \& Boland, R. (2000). Nicotiana glauca: another plant species

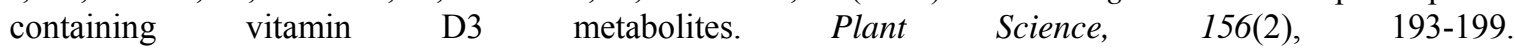
http://dx.doi.org/10.1016/S0168-9452(00)00254-5

Slyn'ko, N. M., Tatarova, L. E., Shakirov, M. M., \& Shul'ts, E. E. (2013). Synthesis of N-aryloxyalkylanabasine $\begin{array}{lllll}\text { derivatives. } \quad \text { Chemistry } & \text { 294-301. }\end{array}$ http://dx.doi.org/10.1007/s10600-013-0585-1

Trease G. E., \& Evans, W. C. (1978). Trease and Evans’ pharmacognosy (11th ed.). London: BalliereTindall.

van Loon, J. J. (1990). Chemoreception of phenolic acids and flavonoids in larvae of two species of Pieris. Journal of Comparative Physiology A, 166(6), 889-899.

Wagner, H., \& Bladt, S. (1996). Plant drug analysis: A thin layer chromatography atlas (2nd ed.). New York: Springer-Verlag Berlin Heidelberg. http://dx.doi.org/10.1007/978-3-642-00574-9

Weber, H. C., \& Kendzior, B. (2006). Flora of the Maltese Islands: A field guide. Weikersheim: Margraf Publishers.

Wright, R. J., Scharf, M. E., Meinke, L. J., Zhou, X., Siegfried, B. D., \& Chandler, L. D. (2000). Larval susceptibility of an insecticide-resistant western corn rootworm (Coleoptera: Chrysomelidae) population to soil insecticides: laboratory bioassays, assays of detoxification enzymes, and field performance. Journal of Economic Entomology, 93(1), 7-13. http://dx.doi.org/10.1603/0022-0493-93.1.7

\section{Copyrights}

Copyright for this article is retained by the author(s), with first publication rights granted to the journal.

This is an open-access article distributed under the terms and conditions of the Creative Commons Attribution license (http://creativecommons.org/licenses/by/3.0/). 